\title{
THEORETICAL FUNDAMENTALS OF CIVIL SERVICE IN THE JUDICIARY IN UKRAINE
}

\author{
Olena Hladunova \\ Postgraduate Student at the Department of State Studies and Law, \\ Odesa Regional Institute for Public Administration, National Academy \\ for Public Administration under the President of Ukraine, Ukraine \\ e-mail: 7itar@i.ua, orcid.org/0000-0003-3489-4746
}

\begin{abstract}
Summary
The article is devoted to the study of the main properties of the civil service in the system of judicial authorities of Ukraine. Theoretical achievements and some legislative norms of formation and functioning of the civil service are outlined in detail. In the context of the conducted scientific research the theoretical bases of civil service in the direction of historical formation, methodological and legal analysis are distinguished. Definitions such as "civil service", "service", "civil servant", their place among the conceptual apparatus in the field of functioning of state bodies are studied. The main differences and similar features of civil service and public service in the judiciary are described, a number of features of civil service in the judiciary are reflected, the status of a civil servant is defined, in particular, in the judiciary, some auxiliary aspects of civil service settlement are given. The definition of the term "civil service in the system of judicial authorities" was formulated and proposed, which allowed to single out and characterize its main features.
\end{abstract}

Keywords: civil service, judiciary, state power, public administration, theoretical foundations.

DOI: https://doi.org/10.23856/4914

\section{Introduction}

In the context of the national policy of reforms and other transformational processes taking place in Ukraine around the civil service, including the one functioning in the judiciary, the need for proper theoretical substantiation of the procedure of its formation, functioning and development became relevant. research.

The theoretical basis of the article are the scientific works of scientists, in particular, Bytyak Yu., Grishchuk A., Lipovska N., Pakhomova T., Petryshyn O., Pismenny I., Seryogin S. etc., devoted to the problems of formation of the civil service, its classification, problematic issues of legal and methodological principles of functioning. At the same time, the science traces a somewhat fragmentary study of the theoretical foundations of civil service in the judiciary, however, today's challenges require a detailed analysis of the abstract - logical basis of this institution of civil service, distinguishing its similarities and opposites in the context of civil service research delineation.

The purpose of the article is to study the theoretical foundations of the civil service in the system of judicial authorities of Ukraine. Thus, we are faced with the task of defining the concept and highlight the main features of the civil service in the judiciary on the basis of analysis of legislation and research. 


\section{Theoretical foundations of historical, legal and methodological nature}

The semantic core of the civil service is the principle of serving the people. It is enshrined in the Law of Ukraine "On Civil Service" as a goal of civil service, and therefore is an expression of its purpose in society. The professional mission of public administration representatives is revealed through public understanding and awareness of the essence and purpose of the civil service (Petrishin, 1999). The service-oriented concept is closer to the domestic civil service and is based on the orientation of civil servants in the performance of civic and moral duties. It is close to the concept of "public service", which is not only the basis of professional appointment of civil servants, but also an important characteristic of the moral maturity of the individual (Lola,2011).

The subject of our study is the institution of civil service in the judiciary. This definition of the subject necessitates the study of such definitions as "civil service", "service", "civil servant", their place among the conceptual apparatus in the functioning of public authorities, including in the judiciary.

Thus, from the point of view of theoretical and historical substantiation, it is worth paying attention to the scientific position of the scientist S. Seryogin, who notes that to this day there is a constant controversy over the content of the term "civil service". This is due to the fact that this concept is quite close to others, such as "public administration", "public service", "public administration", in addition, the substantive nature of these concepts allows us to see their relationship, complementarity in the sense of implementation. However, neither of them exhausts the other. Therefore, the definition of the essence of the civil service should begin with the establishment of the semantic meaning of the service in the general sense. The scholar argues that in the historical context, public service has long been identified with the person of the ruler and his entourage, which is reflected in the works of philosophers of the ancient world - Confucius, Socrates, Plato, Aristotle, Cicero; in the Middle Ages - F. Aquinas, D. Alighieri, M. Luther, N. Machiavelli, T. Hobbes, J. Locke, B. Spinoza, F. Bacon; during the Reformation, Renaissance and bourgeois revolutions - S. Montesquieu, J. Rousseau, I. Kant, G. Hegel and others. In modern times, the civil service is beginning to be interpreted as a bureaucracy - a tool by which in specific social conditions, the will of the state is carried out, as presented in M. Weber's theory of society. Важливими віхами у вивченні державної служби стали дослідження, здійснені M. Weber, W. Wilson and F. Goodnow (the only hierarchically built leadership center for the modernization of human civilization and its achievement of wellbeing), T. Parsons (property of the system associated with the achievement of its common goals), G. Simon ), P. Blau, M. Crozier (humanization of the organization), D. Waldo and W. Ostrom ("sensitive" administration), M. Foucault, E. Giddens (element of communication of modern society), K. Marx (organism-parasite), H. Münsterberg, M. Follett (theory of human relations), J. Century. Milem, G. Mosca (technocratic management). I. Bentham, K. Jaspers, and others also proposed their own paradigms for the organization of state power (Seryogin, 2013). As I. Pismenny and N. Lipovska note, the civil service is in its essence a unique and complex social formation. Polyvalence of interpretation of this phenomenon is conditioned by its existence in the object-procedural form: on the one hand, it is a social phenomenon for the description of which the terms "institute", "system", "organization" are most often used, on the other - a form of social practice, a certain kind professional activity. The authors believe that the civil service as an object of scientific research was simultaneously in the center of attention of several sciences (law, political science, philosophy, economic theory, administrative sciences, sociology, psychology), each of which has formed different interpretations of this complex 
phenomenon. there is no common understanding of the nature of the civil service and its genesis (Pismenny et al., 2015). Emphasizing the transformational approach, scientist A. Hryshchuk argues that during the years of independence of Ukraine developed the constitutional foundations of civil service as a mechanism of public administration, which is fundamentally different from the previous administrative system of government. However, during this period the main task was not solved - the creation of a comprehensive legal framework that would fully ensure the implementation of the Constitution of Ukraine and generally accepted principles and norms of international law. Therefore, a new stage of administrative reform was needed, the most important component of which was the further reform of the civil service (Gryshchuk, 2018:27).

The above point of view somewhat coincides with the position of Yu. Bytyak, which notes that Ukraine has created a system of national legislation on civil service and service in local government as an integral prerequisite for democratic change, the introduction of legal, social and economic standards of human life, society and the state, real improvement of human welfare. At the same time, the system of legislation on public service does not yet fully meet the growing needs of society in democratic transformations and ensuring the effective implementation of the tasks and functions of the state (Bityak ,2005:3).

According to Doctor of Sciences T. Pakhomova, the civil service is a systemic object, the components of which are: state bodies, which are empowered to perform tasks and functions of the state; processes and procedures related to the functioning and development of the civil service as a whole and its elements - civil servants, and their legal regulations; civil servants who directly perform the tasks and functions of the state (Pakhomova, 2007:9).

We support the scientific point of view of S. Seryogin, who interprets that the civil service is a political, organizational, managerial and social institution of the state, which provides a set of relations between individual citizens, citizens and their communities and between states, using government resources. Despite centuries of research on this issue, the problems of the state and government, the principles, forms, mechanisms and means of the state apparatus and civil service remain relevant to this day, due to the following main reasons:

- civil service is one of the components of such a fundamental concept as public power, and civil servants have always been a separate public corporation of people close to power. But according to the classical principles of the corporation, in order to preserve and protect it, it must be in some way closed from external influences on its internal state, which has long been achieved, including using government resources. As a result, state power remained inaccessible for in-depth analysis and research, it is even better to say that researchers who tried to reach the sources, mechanisms, and means of power were not allowed to access information about it. In particular, for many centuries the question of the legitimacy and legitimacy of state power and its bearers has not even been raised, but its unearthly origin has been proclaimed and even asserted;

- in essence, state power is one of the key, large-scale, multifaceted and defining phenomena in the life of human society. And the civil service as a form, mechanism and means of realization by the state of power functions in its epistemological basis combines a large number of spheres and branches of knowledge so that civil service issues are not limited to political science, jurisprudence, sociology or philosophy of power;

- the civil service as an institution of power contains great human potential, so when researching the institutional features of the exercise of government functions and powers, one should always keep in mind the "human factor" of the civil service with all the consequences that follow. Thus, one must take into account the fact that power is exercised precisely through the system of human relations, where the citizen and the official during real communication can be in different, not always adequate economic, political, social, legal, psychophysiological positions and states; 
- despite the recent spread of the idea of general liberalization of state power through the introduction of legal mechanisms for its decentralization, deconcentration, openness, transparency, it is difficult to imagine in practice a modern state, public administration without a developed and branched system of civil service, for only adherents of radical utopian teachings, such as Marxism or anarchism, can predict the gradual "extinction" of the state and bureaucracy. The fact is that the state power and its apparatus are called to perform on the basis of laws, above all, social and regulatory functions - this is their main mission, which should ensure the stable existence of the state and society (Ser'ohin, 2013:64).

Researcher M. Inshin considers the civil service taking into account the factors of labor law as an important factor in regulating public life and the implementation of state tasks and functions. Civil service is understood as a special type of professional activity and a form of realization of the constitutional right to work (Inshin, 2005:7).

Doctor of Science O. Obolensky, also touching on the professional factor, separates the civil service as one of the main activities of the state related to the legal regulation of all aspects of civil servants and the formation of human resources management (Obolensky,2003:61).

In general, referring to the basic definition of "civil service", it can be considered in terms of translation. Thus, the Cambridge Dictionary (Cambridge Dictionary,2021) translates from business English the civil service - the employees and departments of a country's government that are not part of its military. Translated from American English means «all government departments that are not part of the military.»

According to foreign scholar Lijan Sinambela, the term service comes from the word "serve" which means to help provide all that is needed by others for acts of service. Basically every human being needs service, even in the extreme it can be said that service cannot be separated from human life (Sinambela, 2010:3). Another foreign researcher defines "service as an activity carried out by a person or group of people with a certain basis where the level of satisfaction can only be felt by the person serving or being served, depending on the service provider's ability to meet user expectations. (Moenir, 2002:26-27).

Systematically analyzing the definition of "service", M.Tcurcan concludes that the features of this concept are: a) direct focus not on the production of material values, but on creating conditions for material production; b) possession of a specific object of work information that is also a means of influencing (collection, processing, transmission, storage, creation of information) on the objects of management or on the objects of management services; c) connection, as a rule, with mental work; d) payment; e) exercise by persons holding positions in state or municipal bodies, corporate or public organizations. Analysis of forms of government in European countries allows us to conclude that at the same time with the term "civil service" are used terms such as "civil service", "public service", "professional bureaucracy", "public administration" (Tcurcan, 2010:6,7).

According to YU. Bytyak, the civil service in Ukraine is recognized as one of the important institutions in the formation and development of statehood, on which depends the functioning of the entire socio-political system, solving various tasks and functions of the modern state. Civil service is the basis of modern state building, exerts its influence on all major constitutional and legal formations. The scientist argues that the formation of civil service and service in local government, its development, legal regulation are determined by the needs of the state related to its tasks and functions, as the legislative, executive and judicial powers, local government is provided by these bodies and their structural units (Bityak, 2005:7,21).

In addition, as A.B. Gryshchuk, the problems that have accumulated in the formation of a flexible system of government that would meet the socio-political and economic situation in the 
country and serve the citizens, lead to the fact that the administrative apparatus of the authorities slows down reforms in various spheres of politics and economy (Grishchuk, 2018:27).

Nelipa D. believes that the civil service is its element, which practically embodies the main purpose of this activity, as well as ensuring the implementation of basic tasks and functions of the state, the provision of management services and the formation of authority in society (Nelipa, 2012:124).

Revealing the diversity of the civil service through determinant bases, we can demonstrate this definition in view of the following: in procedural terms, the civil service is, above all, the competent work of public officials in the framework of their tasks and functions. Such work can be expressed as the implementation of state functions, as well as society's need for statehood. In addition, as a procedure for the functioning of public authorities within their area of responsibility. Also, as the embodiment of tasks, functions and normative - legal acts of the state, in other words, it is an impartial social phenomenon, which cannot be studied only as the activity of civil servants and administrative bodies. Thus, the state apparatus acts as an integral element, as an institution of civil society. As a structural component, the civil service is a system of bodies, each of which, according to the object of its competence, can be called a service. According to the organizational determinant, the civil service appears as a system of public positions, and such positions are combined into a structure not only by hierarchical concepts, but also by schemes of promotion. In other words, in order to become a mechanism for implementing the functions of public administration, the civil service must take the position of an effective mechanism for regulating the state apparatus itself.

In the context of the social dimension, O. Obolensky describes the social nature of the civil service, emphasizing that such a service is determined by the socio-class composition of civil servants. The scholar argues that any state seeks to create a civil service as a reliable tool for implementing its policies. The reliability of the civil service in a class society is determined by the social composition of officials, their belonging to the ruling class or those social strata of society that support this class, share with it the responsibility for the general state of affairs. Usually in this case the class principle of staffing of the management staff, state structures is used (Obolensky, 2003:43). The social nature of the civil service gives it a number of features that reveal the following substantive aspects: first, it is unique to her field of professional activity. With all its content, forms and methods, this activity is aimed at ensuring the implementation of the powers of state bodies. Second, as a link between the state and the citizen, the civil service is designed to protect the rights and freedoms of citizens. Constitutional provision that "a person, his life and health, honor and dignity, inviolability and security are recognized in Ukraine as the highest social value" (3th Article of the Constitution of Ukraine), acts as a defining core in the activities of civil servants, regardless of their official status. Third, the civil service as a social phenomenon - a kind of reflection of social ties and relations, an indicator of the degree of humanity, humanity, the existing order in society (Obolensky,2003:110).

Civil service in the modern sense is reduced to the implementation of public administration functions, which is considered in a broad sense, ie as the administrative activities of all bodies in the system of legislative, executive and judicial power. Under this approach, the activities of both legislative and executive, as well as judicial bodies of state power fall under the formulation of "government". In other words, public administration in this sense characterizes all the activities of the state associated with the organizing influence of special subjects of law on public relations. This activity is usually carried out by civil servants.

Under the institutional approach, public service is provided by employees of all public sector organizations: public authorities (ie not only the executive, but also the legislature and 
the judiciary), state enterprises and institutions, local governments, utilities and institutions. Thus, the concept of public service includes the activities of employees of all institutions that perform public functions (Kovbasyuk et al., 2012:26,35).

As we can see, the civil service can be separated by the division of branches of government into service in the legislative, executive and judicial branches.

In general, the methodology of research of civil service relations arising in the process of organization and implementation of civil service acts as an institutional and functional analysis, which allows on the basis of constitutionally and legally established functions to determine the necessary composition and public - administrative forms of legal relations, management and functioning of the researched institute of civil service.

\section{The status of a civil servant}

In order to systematically identify further logical possibilities for the analysis of the civil service, we pay attention to the definition of a civil servant.

A number of scholars to civil servants include all persons who: first, work or serve in government agencies or in the apparatus of such bodies; secondly, which is assigned either the rank of civil servant, or class ranks, or military or special ranks; thirdly, which are financed by state funds (Averyanov,2002:393).

It is believed that when reforming the public service in Ukraine, it would be best to follow the following division: on the one hand, to determine the status of a civil servant (he can be called a public civil servant, or "subject of power"), who will perform the most important state functions and powers, perform administrative activities (currently in Ukraine according to the accepted classification of civil servants by type according to the powers that are enshrined both in legislation and in other legal documents - regulations, statutes, decisions, etc., they can include "officials" and "representatives of the administrative authorities"), and on the other - to determine the status of ordinary employees and technical staff (employees) engaged in special tasks and functions in the civil service (these include "specialists" and "support staff"). Such a system has been working effectively for a long time in some countries characterized by a developed system of public service (for example, Germany, France, Belgium, Switzerland, etc.) (Humeniuk,2006).

The characteristic features of civil servants, as well as their types in general can be accepted. However, in our opinion, they should be supplemented with certain explanations and comments, which will allow a more complete description of these phenomena.

First, the definition of a civil servant as a subject of power. Given the provisions of the Law of Ukraine "On Access to Public Information", the subjects of power are public authorities, other state bodies, local governments, authorities of the Autonomous Republic of Crimea, other entities performing government management functions in accordance with legislation and decisions which are binding.

According to the Law on Civil Service, a civil servant is a citizen of Ukraine who holds a civil service position in a public authority, another state body, its staff (secretariat) (hereinafter a state body), receives a salary from the state budget and carries out the powers established for this position, directly related to the performance of tasks and functions of such a state body, as well as adheres to the principles of civil service.

That is, a civil servant is an employee of a state body who is endowed with the authority to perform the tasks of such a body, represents its interests, but in fact is not. Thus, of course, from the point of view of administrative proceedings (CAS of Ukraine) the subject of power may be an official or official of a public authority, local government, however, provided that 
they exercise public authority management functions under the law, in including the exercise of delegated powers, or the provision of administrative services.

M. Vilhushinsky focuses on the fact that power arises and is exercised exclusively within the framework of public law relations or, in other words, is the quintessence of public power and is binding (Vilhushinsky, 2013:11).

Public-legal relations, also called administrative-legal relations, arise between individuals, legal entities of public and private law and subjects of power (holders of public authority) in relation to the exercise by individuals, legal entities of their rights, freedoms, interests, or performance of duties, whether internal organizational legal relations within one subject of power, etc. Therefore, such relations cannot directly characterize the activities of civil servants who are empowered to perform the functions of a public authority.

However, the generalized concept of public service, which includes some civil service positions, is provided by the Code of Administrative Procedure of Ukraine, which defines "public service" as activity in state political positions, in state collegial bodies, professional activity of judges, prosecutors, military service. alternative (non-military) service, other civil service, patronage service in state bodies, service in the authorities of the Autonomous Republic of Crimea, local self-government bodies.

Regulation of the legal status of civil servants working in the apparatus, secretariats of courts and other judicial authorities is carried out in accordance with the Law of Ukraine "On Civil Service".

\section{Serving the state in the judiciary}

It is worth noting that scientists often identify the concept of "civil service" and "public service". Thus, according to R. Golobutovsky, considering the relationship between the concepts of "civil service" and "public service", it should be assumed that the civil service involves service to the state, and public service indicates service to society (people). As public administration is transformed into public administration, the civil service is transformed into a public one. Thus, the public service is an integrated public institution, through which the state implements its tasks and functions, distributing them among the branches of government, government agencies. The researcher believes that one of the elements of public service is service in the judiciary. Depending on the tasks and functions of the judiciary, the following types of public service can be distinguished: a) service as a judge; b) service in the bodies that ensure the activities of courts and judges; c) service in state bodies and institutions of the justice system (Golobutovsky, 2019).

In our opinion, the above statement needs to be specified, as the professional activity of judges and patronage service of their assistants really belongs to the public service, however, the activity of the vast majority of employees of local, appellate and higher specialized courts, the Supreme Court, secretariats of the High Qualifications Commission. Judicial Administration, the High Council of Justice, the Judicial Protection Service are regulated by the legislation on civil service. In such circumstances, in our opinion, it is impossible to talk about the complete transformation of the civil service, in particular, in the system of judicial authorities, into a public one.

In addition, it is interesting that the system of judicial authorities unites the institution of civil service of two branches of government: the executive, such as the SJA of Ukraine and the judiciary - secretariats, the staff of judicial institutions.

We, in general, agree with O. Samarets on the description of the features of civil service in the judiciary, except for the attribution of judges to civil servants, who emphasizes that such civil service is a type of specialized civil service and is distinguished by functional features 
and properties judicial power, the competence of its bodies, which are formed and operate on the basis of special legislation. The service in the judiciary is also distinguished by the criteria of education required to perform the duties of this service. Thus, as a type of specialized civil service, service in the judiciary is characterized by such features as: subject matter and professional specialization; functional purpose; sphere of activity; the legal status of the judiciary in the system of state bodies; special conditions for entering the service, its passing, promotion, evaluation and termination of service; special legal status of judges and civil servants of judicial authorities; special procedure for bringing to legal responsibility. Emphasizes that the civil service in the judiciary has other features in common with other types of civil service, namely: civil service is associated with the implementation of tasks and functions of the state in various spheres of society (implementation of judicial functions); have common general principles and principles of organization and functioning (staffing and organizational structure, rules and regulations, reporting forms, etc.); civil servants perform organizational and administrative and advisory functions; maintenance at the expense of the state budget; recruitment under a special procedure. These are signs of kinship between the specialized civil service in the judiciary and the general civil service (Samarets, 2020:409).

The legal status of civil servants of the judiciary provides for: 1) the presence of power of both internal and external nature; 2) the opportunity to act within its competence on behalf of the state during the supervision of compliance with and proper application of laws by public authorities and local governments, individuals and legal entities, enterprises, institutions and organizations; 3 ) the presence of established restrictions both during the entry into the civil service and during its passage; 4) the availability of guarantees of social and legal protection; 5 ) increased responsibility both for their own actions and for the activities (inaction) of their subordinates (Zolotareva, 2015: 82).

In our opinion, the main problems of civil service in the judiciary are the imperfect system of remuneration, low level of motivation and stimulation of productive activities. In addition, this area is insufficiently regulated. We believe that the reflection of the legal basis of the civil service in the judiciary will serve the professional growth of employees in this area, as well as a clear awareness of their rights, freedoms, interests and responsibilities from a purely professional and social point of view.

In 2020, the results of a sociological survey "Attitudes of Ukrainian citizens to the judiciary" conducted by the Razumkov Center were published, which showed that the level of trust in the courts is influenced by the level of trust in public institutions in general. The study revealed a low level of trust in the judiciary, which is a consequence of the low level of trust in government agencies in general. That is, the distrustful attitude of citizens to the court is largely reflected in the civil service of the courts and other judicial authorities (Zvit,2020).

Researcher Gregg G. Van Rizin argues that the modern efficiency movement tends to suggest that the key to restoring public confidence in civil servants is to focus on results. But there is growing evidence from various fields that trust in people and institutions of power often depends more on the process (eg, justice and equality) than on results. This conclusion that the process is important in the formation of confidential judgments is manifested in a wide range of conditions (police, courts, jobs), but it has not received adequate recognition in the literature on public administration and rhetoric about government, especially in the era focused on result.

But the definition of the process in the movement for efficiency too often does not take into account that there are also some specific government processes or, more precisely, aspects of government processes that are really important in the real life of citizens. But these useful aspects of the process, so to speak, all too often end up being combined with unproductive 
aspects of the process, such as bureaucracy, which serve as a favorite goal of result-oriented reformers. The following is a list of these useful aspects of the process:

- justice (including lack of bias or favoritism);

- justice (in the sense of equal distribution of public goods or in accordance with true needs);

- respect (including politeness and sensitivity to citizens);

- honesty (in the sense of an open, honest process and the absence of corruption) (Van Ryzin, 2011).

From the point of view of scientific achievements of scientists, it is seen that the formation of citizens' trust in civil servants and its consolidation should be a mandatory attribute of the relationship between government and society. Because this sociological and psychological category directly affects the attitude of citizens to government in general. The cohort of civil servants, in particular in Ukraine, including in the judiciary, is a significant layer of public administration, which interacts with citizens on a regular basis in their daily lives. Thus, in the absence of trust, it is unlikely that society will seek to adhere to established rules and procedures and participate in the joint development of important public services for citizens.

Foreign scholars believe that citizens judge civil servants based on perceiving their administrative behavior (process) and by attributing credit or blame for the results of government activity (outcomes). The only way to know for sure is to set up experiments, or look for natural experiments, in which processes and/or outcomes are manipulated in such a way that allows observation of their true causal effect on trust (Remler etc., 2011).

Scientists I. Krynychna and V. Gurkovsky note that ince the civil service is an institution of public service and, due to its organization and corporate cohesion, is one of the factors for stabilizing and ensuring the spiritual and moral security of citizens, the civil servant's competence is manifested not only in the quality of his job performance, but also includes his personal characteristics, features of his social behavior.

Being a comprehensive legal and social institution, the civil service ensures the fulfillment by the civil servants of the constitutional functions of the state, the activities of public authorities, other public bodies, individual public institutions, as well as the powers of persons who fill public positions in Ukraine (Krynychna et al., 2020:32).

The judiciary needs technical staff to function and provide a basis for public access to justice. Judicial staff work with large volumes on a daily basis, requiring special protection of information, which must be properly recorded and stored. Mistakes and omissions can have consequences for people's lives and well-being. Improper disclosure of information can affect the outcome of litigation and put witnesses at risk. Judicial systems, which provide proper management and supervision, recruit qualified staff on the basis of transparent selection of applicants, in which staff are evaluated and rewarded according to their professional qualities, developed and their skills and functions improved through continuous training. in turn to demand from employees a high level of professionalism and honesty. If court staffing is not considered a priority or a function of staff as civil servants, which is not explained to management, the justice system and citizens who turn to it are likely to face inefficient low-quality services as well as corruption. (Dostup k pravosudiyu (Access to justice)).

\section{Conclusions}

In view of the above, in accordance with the goal, we present a number of basic properties of the civil service in the system of judicial authorities, which can be identified on the basis of a study of the basic theoretical principles: 
- performance of state functions in the field of justice;

- unification of the institute of civil service of two branches of government executive and judicial;

- allocation according to the criteria of education necessary for the performance of powers in civil service positions in the judiciary;

- increased responsibility both for their own actions and for the activities (inaction) of subordinate employees;

- quarantees of social and legal protection.

Therefore, we consider it necessary to formulate the following definition of the term "civil service in the judiciary".

Thus, the civil service in the judiciary is a qualified, competent, open, politically neutral activity to perform the tasks and functions of the state in the field of justice, which unites employees of the executive and judicial branches to ensure the provision of quality judicial services, satisfaction of moral security of citizens, while the staffing of the judiciary, which has increased responsibility for their own actions and is allocated according to the criteria of education required to perform the duties of this service, is considered a priority for the state, which guarantees it social and legal protection.

Prospects for further development in this direction, in our opinion, should be devoted to the analysis of the historical - conceptual aspect and features of the institution of civil service in the system of judicial authorities.

\section{References}

1. Averyanov, V. (2002). Vykonavcha vlada i administratyvne pravo [Executive power and administrative law]. Kyiv: Vydavnychyy Dim «In-Yure» [in Ukrainian].

2. Bytiak, YU.P. (2005). Derzhavna sluzhba v Ukrayini: orhanizatsiyno-pravovi zasady [Civil service in Ukraine: organizational and legal principles]. Kharkiv: Pravo [in Ukrainian].

3. Vil'hushyns'kyy, M. (2013). Do pytannya pro sutnist' ta zmist katehoriyi "sub"yekt vladnykh povnovazhen'" [On the question of the essence and content of the category "subject of power"]. Viche - Viche, 12, 10-14 [in Ukrainian].

4. Dostup $k$ pravosudiyu. Sudy [Access to justice. Courts.]. UNODC. Retrieved from https://www.unodc.org/pdf/criminal_justice/10-52547_2_Justice_1_ebook.pdf [in Russian].

5. Holobutovs'kyy, R.Z. (2019) Ponyattya ta oznaky publichnoyi sluzhby v orhanakh publichnoyi vlady Ukrayiny [Concepts and features of public service in public authorities of Ukraine]. Jurnalul juridic national: teorie şi practică - National law journal: theory and practice, 2. Retrieved from http://www.jurnaluljuridic.in.ua/archive/2019/2/part_1/7.pdf 2019 [in Ukrainian].

6. Hryshchuk, A. B. (2018) Derzhavna sluzhba v Ukrayini: administratyvno-pravovyy vymir [Derzhavna sluzhba v Ukrainy: administrativno-pravovyi vymir]. L'viv: L'vivs'kyy derzhavnyy universytet vnutrishnikh sprav [in Ukrainian].

7. Humenyuk, V.A. (2006). Stanovlennya publichnoyi sluzhby $v$ Ukrayini [Formation of public service in Ukraine]. Aktual'ni problemy derzhavnoho upravlinnya - Actual problems of public administration, 2 (29) [in Ukrainian].

8. Zolotar'ova, Ya. (2015) Administratyvno-pravovyy status derzhavnykh sluzhbovtsiv sudovykh orhaniv: teoretychnyy aspekt [Administrative and legal status of civil servants of judicial bodies: theoretical aspect]. Naukovyy visnyk Uzhhorods'koho natsional'noho universytetu - Scientific Bulletin of Uzhhorod National University, 34 (2),80-83 [in Ukrainian]. 
9. Inshyn, M.I. (2005). Problemy pravovoho rehulyuvannya pratsi derzhavnykh sluzhbovtsiv Ukrayiny [Problems of legal regulation of labor of civil servants of Ukraine]. Extended abstract of Doctor's thesis. Odesa: Odes'ka natsional'na yurydychna akademiya [in Ukrainian].

10. Kovbasyuk, YU. V., Obolens'kyy, O. YU., Ser'ohin, S. M.ta in. (2012). Derzhavna sluzhba [Civil Service]. Odesa : NADU [in Ukrainian].

11. Krynychna, I. \& Gurkovskii, V. (2020). Professional competence as a factor of the efficiency of the activity of a public servant. Public Administration and Law Review, 1, 30-38. Retrieved from https://public.scnchub.com/palr/index.php/palr/article/view/12/4 https://doi.org/10.36690/2674-5216-2020-1-30-38 [in English].

12. Lola, V.V. (2011). Profesiyna misiya personalu publichnoyi vlady sluzhby [Professional mission of public service personnel]. DRIDU NADU - DRIDU NADU. Retrieved from http://www.dridu.dp.ua/vidavnictvo/2011/2011_03(10)/11lvvppv.pdf [in Ukrainian].

13. Moenir, H.A.S (2002). Manajemen Peläyanan Umum di Indonesia [Public Service Management in Indonesia]. Jakarta : Bumi. Aksara [in Indonesian].

14. Nelipa, D.V. (2012). Orhanizatsiyno-pravovi zasady derzhavnoyi sluzhby v Ukrayini [Organizational and legal principles of civil service in Ukraine]. Kyiv: Tsentr uchbovoyi literatury [in Ukrainian].

15. Obolens'kyy, O. YU. (2003). Derzhavna sluzhba [Civil service].Kyiv: KNEU. [in Ukrainian]. 16. Obolens'kyy, O. YU. (2003). Derzhavna sluzhba [Civil service: Textbook].Kyiv: KNEU. [in Ukrainian].

17. Pakhomova, T. I. (2007). Mekhanizmy funktsionuvannya systemy derzhavnoyi sluzhby $v$ period suspil'nykh reform [Mechanisms of functioning of the civil service system in the period of social reforms]. Extended abstract of Doctor's thesis. Kyiv : Vydavnytstvo NADU [in Ukrainian].

18. Petryshyn, O.V. (1999). Pravovyy rezhym derzhavnoyi sluzhby: pytannya zahal'noyi teoriyi [Legal regime of civil service: questions of general theory]. Extended abstract of Doctor's thesis. Kharkiv: Natsional'na yurydychna akademiya Ukrayiny im. Yaroslava Mudroho [in Ukrainian].

19. Pys'mennyy, I., \& Lypovs'ka N. (2015). Vydy derzhavnoyi sluzhby: teoretychna polemika [Types of public service: theoretical controversy]. Derzhavne upravlinnya ta mistseve samovryaduvannya - Public administration and local self-government, 4, 200-210 [in Ukrainian].

20. Remler, Dahlia K \& Van Ryzin, Gregg G. (2011) Research methods in practice: Strategies for description and causation, Los Angeles, CASage. Retrieved from https://books.google.com. ua/books?hl=ru\&lr=\&id=2iI_EAAAQBAJ\&oi=fnd\&pg $=P T 28 \& o t s=f u F W H j Y n G S \& \operatorname{sig}=v E-$ w1rKY6bxkt5y2f7wPitcq1E0M\&redir_esc $=y \# v=$ onepage \&q\&f=false[in English].

21. Sait «Cambridge Dictionary» [Site of Cambridge Dictionary]. dictionary.cambridge.org/ ru Retrieved from https://dictionary.cambridge.org/ru [in Russian].

22. Samarets', O.I. (2020). Sutnisni vlastyvosti derzhavnoyi sluzhby v orhanakh sudovoyi vlady Ukrayiny [Essential properties of the civil service in the judiciary of Ukraine]. Yurydychnyy naukovyy elektronnyy zhurnal - Law scientific electronic journal, 7, 407-409 [in Ukrainian].

23. Ser'ohin, S. M. (2013). Meta, zavdannya ta funktsiyi derzhavnoyi sluzhby [Purpose, tasks and functions of the civil service]. Aspekty publichnoho upravlinnya-Aspects of public administration, 1, 58-65 [in Ukrainian].

24. Sinambela, Lijan Poltak (2010). Reformasi Pelayanan Publik, Teori Kebijakan dan Implementasi [Public Reform, Public Theory and Implementation]. Cetakan kelima, Jakarta : PT Bumi Aksara [in Indonesian]. 
25. Tsurkan, M. I. (2010) Pravove rehulyuvannya publichnoyi sluzhby v Ukrayini. Osoblyvosti sudovoho rozhlyadu sporiv [Legal regulation of public service in Ukraine. Features of litigation]. Kharkiv: Pravo [in Ukrainian].

26. Van Ryzin, Gregg G. (2011) Outcomes, Process, and Trust of Civil Servants. Journal of Public Administration Research and Theory, Volume 21, Issue 4, Pages 745-760. Retrieved from https://academic.oup.com/jpart/article/21/4/745/954991?searchresult=1

27. https://doi.org/10.1093/jopart/muq092 [in English].

28. Zvit za rezul'tatamy doslidzhennya «Stavlennya hromadyan Ukrayiny do sudovoyi systemy» [Report according to the results of the study "Attitudes of Ukrainian citizens to the judicial system"]. (2020). Kyiv: Hromads'ka orhanizatsiya Ukrayins'kyy tsentr ekonomichnykh i politychnykh doslidzhen' imeni Oleksandra Razumkova [in Ukrainian]. 